\title{
Beta-propiolactone as an agent for enzyme sterilization
}

\author{
K. J. STOKES
}

From the Group Laboratory, Mayday Hospital, Thornton Heath, Surrey

SYNOPSIS A chemical method for the sterilization of pancreatin and trypsin is given. Evidence is presented to show that this treatment does not diminish the specific activity of the enzymes and hasi some advantages in microbiological techniques.

Beta-propiolactone (BPL) is of value as a sterilizing agent because it causes negligible alteration to the antigenic structure of microorganisms (Sever, Castellano, Pelon, Huebner, and Wolman, 1964), and, since it is rapidly hydrolysed to beta-hydroxypropionic and beta-chloropionic acids, needs no subsequent removal (Peck, 1960). It therefore seemed reasonable to expect that enzyme solutions could also be sterilized by this agent.

Pancreatin and trypsin solutions used in microbiology are usually prepared by an aseptic technique or sterilized by membrane filtration. This investigation was undertaken to see if BPL affected specific enzyme activity and if the hydrolytic breakdown products of BPL resulted in inhibition of microorganisms or tissue cells after they had been treated by the enzymes.

\section{Materials and Methods}

Beta-propiolactone (British Drug Houses) was stored at $-20^{\circ} \mathrm{C}$. Crystalline trypsin (Novo Industries) was stored at $+4^{\circ} \mathrm{C}$. Buffered pancreatin tablets (Oxoid) were stored at room temperature. A glass electrode Beckman $p \mathrm{H}$ meter was used for $p \mathrm{H}$ estimation. Virus titres were estimated by the method of Reed and Muench (1938) using four tubes per dilution.

Two enzyme solutions in common use are buffered pancreatin/trypsin (P/T) for the liquefaction of sputa, as described by Rawlins (1968), and trypsin $0.25 \%$ in balanced salt solution for the disaggregation of cells in tissue culture work. These solutions and a solution of buffered pancreatin (Rawlins, 1955) were prepared in $50 \mathrm{ml}$ amounts. One $\mathrm{ml}$ of a $1 / 15 \mathrm{v} / \mathrm{v}$ solution of BPL in cold deionized water was added

Received for publication 6 January, 1971. to $50 \mathrm{ml}$ of enzyme solution prewarmed to $37^{\circ} \mathrm{C}$.. The requisite amount of caustic soda determined by $\vec{\circ}$ preliminary trials was added and the mixture shaken for two minutes at room temperature. The solutions 0 were decanted into fresh sterile bottles to avoid@ subsequent contamination of the treated solution $\vec{\varphi}$ with untreated enzyme present round the necks of the bottles. Treatment continued for 90 minutes in a $37^{\circ} \mathrm{C}$ water bath, with shaking at 15 -minute intervals. After treatment storage was at $4^{\circ} \mathrm{C}$.

\section{Proteolytic Activity}

This was estimated by Harrison's modification of $\overrightarrow{\overrightarrow{0}}$ Kniaskof's method (Harrison, 1943). Serial twofold 3 dilutions of treated and untreated enzymes were? made in normal saline. One drop of each dilution was? placed onto a section of exposed photographic film, which was incubated at $37^{\circ} \mathrm{C}$ for 15 minutes in a? humidified chamber. The film was flooded with cold 3 water and enzyme activity was shown by a clearly punched hole in the emulsion. The results are shown in Table I. In numerous trials no differences were detected.

\section{Sterilizing Ability of BPL 1/750 v/v}

Five common laboratory contaminants, viz, Micrococcus sp., Alkaligenes faecalis, Enterobacter aerogenes, Pseudomonas aeruginosa, and a Candida sp. $\omega$ recently isolated from routine cultures, were grown? overnight on blood agar. The growth was scrapede into quarter strength Ringer's solution and a viable count carried out. Aliquots of each suspension, $\stackrel{+}{+}$ containing $5 \times 10^{8}$ viable organisms per millilitre, $\frac{T}{0}$ were mixed and $0.5 \mathrm{ml}$ of the mixture added to $50 \mathrm{ml} \frac{\mathrm{P}}{\mathrm{D}}$ lots of untreated enzyme. To each bottle $0.5 \mathrm{ml}$ of a suspension of Bacillus subtilis (NCTC 10073) $\stackrel{\mathbb{Q}}{\circ}$ 


\begin{tabular}{|c|c|c|c|c|c|c|c|}
\hline \multirow[t]{3}{*}{ Enzyme } & \multirow{2}{*}{\multicolumn{2}{|c|}{ Aseptically Prepared }} & \multicolumn{5}{|c|}{ BPL Sterilized } \\
\hline & & & \multicolumn{2}{|c|}{ Before $\mathrm{pH}$ Adjustment } & \multicolumn{3}{|c|}{ After $\mathrm{pH}$ Adjustment } \\
\hline & $\mathrm{p} H$ & Titre & $\mathrm{p} H$ & Titre & $N / N a O H(m l)$ & $\mathbf{p} H$ & Titre \\
\hline $\begin{array}{l}\text { Pancreatin } \\
\text { Trypsin } \\
\text { Pancreatin/trypsin }\end{array}$ & $\begin{array}{l}7 \cdot 5 \\
7 \cdot 4 \\
7 \cdot 4\end{array}$ & $\begin{array}{l}1 / 64 \\
1 / 64 \\
1 / 128\end{array}$ & $\begin{array}{l}5 \cdot 3 \\
5 \cdot 0 \\
5 \cdot 2\end{array}$ & $\begin{array}{l}1 / 32 \\
1 / 32 \\
1 / 64\end{array}$ & $\begin{array}{l}1 \cdot 0 \\
1 \cdot 1 \\
1 \cdot 05\end{array}$ & $\begin{array}{l}7 \cdot 6 \\
7 \cdot 6 \\
7 \cdot 6\end{array}$ & $\begin{array}{l}1 / 64 \\
1 / 64 \\
1 / 128\end{array}$ \\
\hline
\end{tabular}

Table I Proteolytic activity and $\mathrm{pH}$ of treated and untreated enzymes

spores, containing $4.8 \times 10^{7}$ spores per millilitre was also added. Each millilitre of the untreated enzyme solutions therefore contained $1 \times 10^{6}$ of the five vegetative bacterial species and $4.8 \times 10^{5}$ spores. One bottle of each contaminated enzyme was retained as a control while the remainder were treated with BPL. After incubation at $37^{\circ} \mathrm{C}$ for 24 hours viable counts were made from each bottle on blood agar and Sabauraud's agar plates. No growth of any organism was obtained from any of the treated bottles whereas recovery of the six bacteria from the control bottles was virtually $100 \%$.

\section{Shelf Life at $4^{\circ} \mathrm{C}$}

Beta-propiolactone-treated and aseptically prepared pancreatin/trypsin were stored in the refrigerator for for one month and checked at two-day intervals for sterility and their ability to liquefy purulent sputa. There was no difference in activity, but four out of six unopened bottles of aseptically prepared pancreatin/trypsin were contaminated after two weeks' storage. All six bottles of BPL-treated pancreatin/ trypsin were sterile after four weeks' storage.

\section{Bacterial Inhibition by Breakdown Products}

One hundred and ninety two random sputa were liquefied, half with aseptically prepared $P / T$ and half with BPL sterilized pancreatin/trypsin. The organisms isolated from the sputa are shown in Table II. The isolation rates showed no significant differences at any level when tested by the $\chi^{2}$ distribution.

\section{Tissue and Viral Inhibition by Breakdown Products}

Hela and monkey kidney cell monolayers, disaggregated with membrane-filtered trypsin solution and with BPL-sterilized trypsin, were seeded into tubes

\begin{tabular}{|c|c|c|c|c|c|c|}
\hline \multirow[t]{2}{*}{ Isolation } & \multicolumn{2}{|c|}{ Mucoid and Salivary Sputum } & \multicolumn{2}{|c|}{ Mucopurulent Sputum } & \multicolumn{2}{|c|}{ Purulent Sputum } \\
\hline & Standard & $B P L$ & Standard & $B P L$ & Standard & $B P L$ \\
\hline $\begin{array}{l}\text { Haemophilus infuenzae } \\
\text { Streptococcus pneumoniae } \\
\text { Staphylococcus aureus } \\
\text { Streptococcus pyogenes } \\
\text { Coliform } \\
\text { Proteus sp. } \\
\text { Pseudomonas aeruginosa } \\
\text { Candida sp. } \\
\text { Normal flora }\end{array}$ & $\begin{array}{c}5(8.6 \%) \\
3(5 \cdot 1 \%) \\
2(3.5 \%) \\
-\quad-(15.5 \%) \\
3(5 \cdot 1 \%) \\
-\overline{9}(15.5 \%) \\
27(46.7 \%)\end{array}$ & $\begin{array}{c}2(3.8 \%) \\
4(7.5 \%) \\
1(1.9 \%) \\
1(1.9 \%) \\
6(11.3 \%) \\
4(7.5 \%) \\
3(5.7 \%) \\
6(11.3 \%) \\
26(49.1 \%)\end{array}$ & $\begin{array}{l}4(12.9 \%) \\
2(6.5 \%) \\
5(16.1 \%) \\
2(6.5 \%) \\
3(9.7 \%) \\
2(6.5 \%) \\
5(16.1 \%) \\
8(25.7 \%)\end{array}$ & $\begin{array}{ll}6 & (18.7 \%) \\
8 & (25.0 \%) \\
1 & (3.1 \%) \\
2 & (6.3 \%) \\
2 & (6.3 \%) \\
1 & (3.1 \%) \\
1 & (3.1 \%) \\
3 & (9.4 \%) \\
8(25.0 \%)\end{array}$ & $\begin{array}{c}3(17.6 \%) \\
2(11.8 \%) \\
2(11.8 \%) \\
-2(11.8 \%) \\
-1(5.9 \%) \\
3(17.6 \%) \\
4(23.5 \%)\end{array}$ & $\begin{array}{l}5(19.3 \%) \\
2(7.6 \%) \\
3(11.6 \%) \\
-5(19.3 \%) \\
-2(- \\
2(7.6 \%) \\
5(19.3 \%) \\
4(15.3 \%)\end{array}$ \\
\hline Totals & $58(100 \%)$ & $53(100 \%)$ & $31(100 \%)$ & $32(100 \%)$ & $17(100 \%)$ & $26(100 \%)$ \\
\hline
\end{tabular}

Table II Isolations from 192 graded sputa treated with standard and BPL-treated pancreatin/trypsin 1

${ }^{1}$ Total isolates more than total sputa due to some multiple isolations.

\begin{tabular}{|c|c|c|c|c|}
\hline & \multicolumn{2}{|c|}{ Monkey Kidney Cells } & \multicolumn{2}{|l|}{ Hela Cells } \\
\hline & Filtered Trypsin & BPL-treated Trypsin & Filtered Trypsin & BPL-treated Trypsin \\
\hline $\begin{array}{l}\text { Time for confluence } \\
\text { Duration of maintenance } \\
\text { Virus titre after } 4 \text { days' growth }\end{array}$ & $\begin{array}{l}4.5 \text { days } \\
15 \text { days } \\
4 \cdot 1 \times 10^{4}\end{array}$ & $\begin{array}{l}4 \text { days } \\
16.5 \text { days } \\
4.3 \times 10^{4}\end{array}$ & $\begin{array}{l}4.5 \text { days } \\
14 \text { days } \\
2 \cdot 5 \times 10^{3}\end{array}$ & $\begin{array}{l}4.5 \text { days } \\
14 \text { days } \\
2 \cdot 3 \times 10^{2}\end{array}$ \\
\hline
\end{tabular}

Table III Growth of cells and virus with cells treated with filtered and BPL-treated trypsin ${ }^{1}$

${ }^{1}$ Each tube seeded with $10^{6}$ cells, virus inoculum $1 \times 10^{2} \mathrm{TCID}^{\text {so, }}$, each result the mean of two trials. 
at identical levels. Growth medium was added and stationary incubation carried out at $37^{\circ} \mathrm{C}$. Time taken for the monolayer to reach confluence, duration of maintenance, and ability to support the growth of influenza virus A2/Hong Kong/68 variant were compared. No significant differences were observed, as shown in Table III.

\section{Discussion}

The concentration of BPL chosen was $1 / 750 \mathrm{v} / \mathrm{v}$ as being halfway between the $1 / 1,000 \mathrm{v} / \mathrm{v}$ concentration used for virus vaccines and the 1/500 concentration used for preparation of inactivated bacterial antigens. This is a simple technique requiring few facilities and ensures sterility where moderate levels of contamination are involved. There is clear evidence that bacterial growth is not inhibited and more limited evidence that tissue and viral growth is unaffected. The effect of BPL on other enzymes, active at different $p \mathrm{H}$ levels, was not investigated. The two clear advantages that emerge are certain sterility, even in the hands of inexperienced technicians, due to the lack of aseptic dispensing at any stage, and the resulting prolonged storage life. No attempt has been made to weigh any other advantages or disadvantages of this method over filtration or aseptic preparation, as these may vary according to the circumstances of each particular laboratory. These results do suggest that a wider application may be possible.

Beta-propiolactone irritates the eyes, can be a vesicant on the skin, and is carcinogenic in rats and $\stackrel{0}{\overrightarrow{7}}$ mice (Roe and Salaman, 1958; Dickens and Jones, 1961). The last two workers investigating the carcinogenic activity of lactones and related $\stackrel{?}{+}$ structures in rats found that penicillin $G$ was also productive of transplantable neoplasms, though less active than beta-propiolactone. It is therefore? recommended that suitable precautions be observed $\stackrel{\mathbb{Q}}{\circ}$ with the pure liquid, and that manipulations should be made with due care.

I wish to thank Dr W. R. G. Thomas for guidance $\vec{\omega}$ in the preparation of this manuscript and the statistical evaluation of the results, and Miss E.용 Pipe for technical assistance.

References

Dickens, F, and Jones, H. E. H. (1961). Carcinogenic activity of a series of reactive lactones and related substances. Brit. J.으 Cancer, 15, 85-100.

Harrison, G. A. (1943). Chemical Methods in Clinical Medicine, 2nd ed, pp. 481-482. Churchill, London.

Peck ,F. B., Jr. (1960). Sterilization of biological products with beta- $\frac{?}{1}$ propiolactone. (Letter to the Editor). J.Amer. med. Ass., 174, 1883. 음

Rawlins, G. A. (1955). A method for liquefying sputum for the cultured of organisms other than M. tuberculosis.J. med. Lab. Technol., 13, $133-143$.

Rawlins, G. A. (1968). Use of a pancreatin-trypsin solution for the liquefaction of sputa for routine bacteriological examination J. clin. Path., 21, 531-532.

Reed, L. V., and Muench, H. (1938). A simple method for estimatingo fifty per cent endpoints. Amer. J. Hyg., 27, 493-497.

Roe, F. J. C., and Salaman, M. H (1958). Sterilization of arteriaß grafts. (Letter to the Editor). Brit. med. J., 1, 942.

Sever, J. L., Castellano, G. A., Pelon, W., Huebner, R. J., and Wolman F. (1964). Inactivation of the infectivity of viral haemag-D glutinating antigens with the use of betaprone. J. Lab. Clin. Med., 64, 983-988. 